\title{
"He thought the Māori did not use their land ...": the Wastelands in 1840s landscape painting [propaganda]
}

Tyson Schmidt, Ngāti Porou, wannabe architect

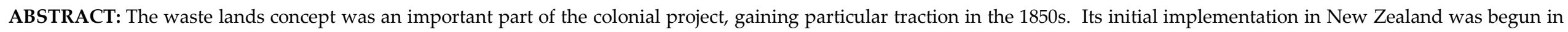

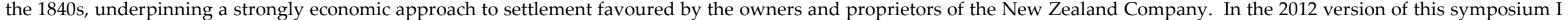

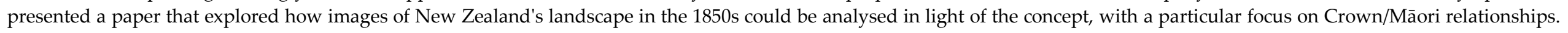

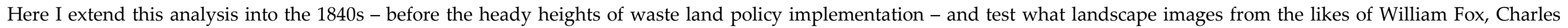
Heaphy, and publications such as Edward Jerningham Wakefield's Adventures in New Zealand can reveal when read through the lens of the waste lands concept.

The 1840s encompassed the rise and fall of the New Zealand Company. Hopes were high early on, with the then recent colonisation experience of South Australia being transplanted over to New Zealand. By the mid-1840s the New Zealand Company was struggling financially, only bailouts by the British Government saving it from going bankrupt. By 1852 the Company had been responsible for about 14,000 of the 18,000 settlers who came directly from Britain since 1840, helping the European population in New Zealand reach 28,000 by 1852 . Edward Gibbon Wakefield saw this as a failure, resigning in 1846 in disgust at the government bailouts and instead pointing to a potential population of 200,000 had the Company been left to trade out of its 1840 s difficulties. The Company was finally wound-up in 1858 .

Historians prefer to focus on the 1860 s to 1880s when looking at the European populating of New Zealand. James Belich calls this absolutely correct if the focus is purely on the numbers. ${ }^{1}$ From 1856 to 1881 the population increased just over 110,000 to more than 530,000 (with Māori declining by 10,000). ${ }^{2}$ Such numbers dwarf the 14,000 settlers that the New Zealand Company brought in. The 20 years from 1860 continues to dominate New Zealand's demographic history, with nearly $30 \%$ of New Zealand's total net migration gains between 1840 and 2000 happening between 1861 and $1880 .^{3}$

But nations are rarely built on reality. The New Zealand Company was vital in establishing myths and stories that laid the foundations for the later population growth.

\footnotetext{
${ }^{1}$ Belich Making Peoples p 279.

2 Pool "Population change" n.p.

${ }^{3}$ Total net migration is the sum of people coming into

New Zealand less those leaving. Pool "Population change" n.p.
}

One way it did this was through intellectual and political influence over the first New Zealand Parliaments in the 1850s, and the inspiration and leadership it gave to provincial settlement associations in places like Otago and Canterbury. The other way was through the significant use of visual and written material to sell New Zealand as a destination and viable settlement. The Company's propaganda reached hundreds of thousands, if not millions, of people in Europe, forming "the idea of New Zealand in British minds." ${ }^{4}$ While the 1860 s to 1880 s saw the building of the population, you could say the 1840s saw the building of New Zealand as a spatial construct.

\section{hijacked by commercial means}

In reviewing Selling the Dream: The Art of New Zealand Tourism, Guy Somerset encourages us

${ }^{4}$ Belich Making Peoples p 282. 
to imagine an alternative history of New Zealand art where we celebrated the designers of posters and billboards rather than fine artists such as Rita Angus, Toss Woollaston and Colin McCahon. Co-editor Peter Alsop notes that the "fine arts community is quite disparaging about posters as artworks and looks down upon them," the commercial focus of designers such as Leonard Mitchell, Marcus King and Howard Mallitte meaning their contribution to creating a national identity was largely ignored before Selling the Dream was published. ${ }^{5}$

A similar attitude has afflicted our view of artists such as William Fox, Charles Heaphy, Samuel Brees and William Mein Smith. Their imagery is remembered primarily through an art history lens, reinforcing the distaste of commercial application by separating aesthetic interest from social or political context. Gordon Brown and Hamish Keith divide colonial painting into two types - a topographical tradition of the earlier period and a "much more cultivated activity which developed from the [1860s] on."6 Works

\footnotetext{
${ }^{5}$ Somerset "Selling the Dream" p 45.

${ }^{6}$ Brown \& Keith New Zealand Painting p 13. EH

McCormick took it further, "thinking topography truth,
} and so established truth or untruth to New Zealand as produced with an almost exclusively topographical intention are tagged with being "produced for purposes entirely unrelated to art." 7 The divisional approach goes beyond time, and can also apply to bodies of work by individual artists. The fine art qualities in Charles Heaphy's later paintings are noted as being "somewhat submerged in his other early works," having been "quite possibly coloured by their intended employment as visual propaganda."8 While William Fox receives the accolade of being "perhaps the first painter to capture the essence of the local landscape in a natural and unpretentious way," several watercolours produced on his settlement scouting trip to the Wairarapa with Samuel Brees are dismissed as holding "little interest as paintings." 9

A similarly divisive view was ushered in by Francis Pound when he criticised Brown \& Keith's belief in a "real" New Zealand landscape whose essence must be truthfully

the frame through which topographers and more

"cultivated" artists are now conventionally seen." Pound Frames on the Land $\mathrm{p} 16$.

${ }^{7}$ Brown \& Keith New Zealand Painting $\mathrm{p} 13$.

${ }^{8}$ Brown \& Keith New Zealand Painting p 30.

${ }^{9}$ Brown \& Keith New Zealand Painting pp 35, 37. represented. ${ }^{10}$ But Pound sought to remove the value judgement from the distinction between topographic and the more "cultivated" activity, placing them as part of a range of approaches (frames) that artists applied. Instead he divided landscapes into a range of genres and their intended purposes "If the landscape genre be the Ideal, the artist is enabled by it to make you feel "how beautiful"; if topography, "that's how it is"; if Sublime, "how overwhelming"."11 There was no "real" New Zealand landscape tradition waiting to be discovered, just existing genres being applied to the New Zealand context. But genre analysis told us little about intentions and the cultural lens being brought to bear.

A decade later the division was removed altogether, with Leonard Bell and WJT Mitchell extending Pound's analysis. Bell warns us against viewing the works of artists such as Heaphy, Brees, Fox and Mein Smith in "isolation, simply as aesthetic objects or ethnological specimens"12 and Mitchell asks us to "explore the ideological use of their

\footnotetext{
${ }^{10}$ Pound Frames on the Land $\mathrm{p} 11$

${ }^{11}$ Pound Frames on the Land $\mathrm{p} 13$.

${ }^{12}$ Bell Colonial Constructs p 5.
} 
conventions in a specific place and time."13 Examining the images within their context can reveal their connection to colonialist ideology and practice, part of a complex story in which "the images contributed to the making of the colonial reality."14 It's not that art historians such as Brown and Keith ignored these aspects, just that they didn't embrace it perhaps best reflected in their statement that "[p]ainting in this initial period [till the 1860s] was in itself something of a colonising activity." ${ }^{15}$ Bell and Mitchell's refinements remove the "something" - you cannot separate the painting from the act of the colonisation.

The use of images by the New Zealand Company is an important part of our spatial history - New Zealand had to be imagined and constructed before it could be claimed. Following Paul Carter's introduction of spatial history in The Road to Botany Bay, Giselle Byrnes notes that "the British came to possess New Zealand not only by proclamation, purchase, conflict and confiscation, but also by controlling its interpretation."16 Rather than space being a passive stage upon which

\footnotetext{
${ }^{13}$ Landscape and Power $\mathrm{p} 23$.

${ }^{14}$ Bell Colonial Constructs p 7.

${ }^{15}$ Brown \& Keith New Zealand Painting p 13.

${ }^{16}$ Byrnes Boundary Markers p 4.
}

history took place, the stage itself was a construction. Edward Gibbon Wakefield was well aware of the need to control this construction, with the visual imagery of Fox, Brees, Heaphy and Mein Smith a vital part of this control (you can call it propaganda or marketing if you want).

\section{the unsparing use of every species of puff ${ }^{17}$}

In one way it is a compliment to the New Zealand Company that James Belich can so clearly state that in the late 1830s "most British had never heard of [New Zealand]."18 By the early 1840 s the machine aimed at constructing the image of New Zealand was so well underway that commentators noted it had been so successful in

identifying themselves with New Zealand in the public eye ... [they] have taught the public to think of New Zealand only through the medium of the New Zealand Company. ${ }^{19}$

The need for such speed was driven by the fierce competition from other countries such as Canada, the United States, South Africa, and Australia for the prospective settler's

\footnotetext{
${ }^{17}$ Heale New Zealand and the New Zealand Company $\mathrm{p} 9$. ${ }^{18}$ Belich Making Peoples p 283.

${ }^{19}$ Heale New Zealand and the New Zealand Company p 9, quoted in Johnston "Information and Emigration" p 61
}

attention. ${ }^{20}$ The groundwork was laid by Edward Gibbon Wakefield's influence in political and business spheres, but to be heard above the colonisation noise meant reaching directly to the people on the street (Wakefield also didn't want to leave it to ministers \& MPs, as they often leant the way of the Crown rather than the Company). The tools used to reach his targets were so effective that James Belich simply states "Wakefield knew exactly what he was doing." 21

The New Zealand Company utilised a wide range of publications to push its message, with a particular focus on newspapers and journals as a way to reach the general public. ${ }^{22}$ From its launch till the end of the 1840s the Company published at least 20 books and some 50 pamphlets. ${ }^{23}$ This was only a portion of its output, as Judith Johnston also notes advertisements, emigration handbooks, brochures, and guides as other print output

${ }^{20}$ Minson "Promotional Shots" p 159. Belich Making Peoples p 278.

${ }^{21}$ Belich Making Peoples p 282.

22 Johnston "Information and Emigration" p 61.

${ }^{23}$ Belich Making Peoples p 282. Phillip Temple puts the number of Company books on New Zealand at over 200 over fifteen years, including those published by

Wakefield-initiated associations and companies. Temple A Sort of Conscience $\mathrm{p} 195$. 
by the Company.24 Edward Gibbon Wakefield ensured the volume and reach was maintained by negotiating the continued insertion of New Zealand news with editors of smaller newspapers as well. ${ }^{25}$ New Zealand's first newspapers were either owned or heavily controlled by the Company (though this influence waned from the mid-1840s onward). ${ }^{26}$ While other researchers have noted the limited literacy of some of the Company's target market, the marketing campaigns were still achieving impressive reach - for example, the Chambers Edinburgh Journal "sold 100,000 copies a week and possibly reached over one million readers." 27

Visual imagery played a major role in the New Zealand Company marketing machine lithographs, engravings, paintings, and panoramas were all used. The Companybacked panorama displays at Leicester Square by Robert Burford (from drawings by Augustus Earle) in the late 1830s and by Samuel Brees in the late 1840s. Burford \&

\footnotetext{
${ }^{24}$ Johnston "Information and Emigration" p 61.

${ }^{25}$ Johnston "Information and Emigration" p 61.

${ }^{26}$ Day Making of the New Zealand Press pp 12-34.

${ }^{27}$ Johnston "Information and Emigration p 61. See

Minson "Promotional Shots" for a brief discussion on literacy of the Company's target market.
}

Earle's panorama was so popular that Ensign Best thought it needless to describe the Bay of Islands in his 1840s journal since "everybody had seen the panorama in Leicester Square."28 Samuel Brees' panorama of New Zealand had been shown to London audiences approximately 2,000 times by late 1851, with Robin Skinner estimating that the "total audience could easily have been in excess of 40,000."29 Reviews of Brees' panorama mentioned the sale of settler land as much as the panorama itself, showing that there was little separation between artistic entertainment and colonial advertisement. ${ }^{30}$

While regular ship visits brought drawings and paintings back from New Zealand for display at the Company's head office or at exhibitions, it was the lithographs and engravings that better matched the marketing reach Wakefield sought. They allowed multiple copies to be made and utilised in a range of ways. Copies of most sketches and

${ }^{28}$ Best Journal 1837-1843 p 279. The panorama's popularity also meant it was displayed in New York, extending the reach of the New Zealand Company's message. Temple A Sort of Conscience p 196.

${ }^{29}$ Skinner "Representations of architecture" p 82 (n113)

${ }^{30}$ Skinner "Representations of architecture" pp 84-90. Brees Pictorial Illustrations of New Zealand. paintings were distributed not only to the Company agents (which numbered more than 90 across Britain by the early 1840s) but also to libraries, museums, reading rooms, and book sellers. ${ }^{31}$ Lithographs were also priced low to be "within the reach of a large class of the persons interested in the colony."32 This wasn't done through reducing the cost of reproduction though, with prominent lithographers such as Thomas Allom and Henry \& Harden Melville commissioned to do the work. ${ }^{33}$

Newspapers, journals and books also carried versions of the paintings and drawings sent back by the likes of Heaphy, Fox, Brees and Mein Smith. Publications such as the New Zealand Journal and New Zealand Spectator often reviewed the latest lithographs, and in some cases also printed engravings or woodcuts for their readers to peruse. Charles Heaphy's watercolour "Thorndon Flat, and Part of the City of Wellington" arrived in London in May 1841 and was included as a half-page woodcut in a September edition of

\footnotetext{
${ }^{31}$ Johnston "Information and Emigration" pp 62, 64. 32 Murray-Oliver "An Enquiry into Certain Nineteenth Century Prints" pp 86-87.

${ }^{33}$ Murray-Oliver "An Enquiry into Certain Nineteenth Century Prints" pp 86-87; Bagnall et al "S.C. Brees" p 42.
} 
the New Zealand Journal. ${ }^{34}$ In January 1847 the Illustrated London News previewed Brees' upcoming Pictorial Illustrations of New Zealand by printing engravings of three of his sketches, following up with a further two sketches in September to coincide with the publication of the book. ${ }^{35}$ The Company's images of New Zealand proved popular in book form - the success of Brees' Pictorial Illustrations led him to create the Leicester Square panorama, ${ }^{36}$ and Heaphy's views of Wellington from 1841 were reproduced as frontispieces of illustrations to a number of books during the 1840s. ${ }^{37}$

\section{much more faithful to the original}

Charles Heaphy began his three-year New Zealand Company career with a trip aboard

${ }^{34}$ Murray-Oliver "An Enquiry into Certain Nineteenth Century Prints" pp 76-77.

${ }^{35}$ Bagnall et al "S.C. Brees" p 41.

${ }^{36}$ Bagnall et al "S.C. Brees" $\mathrm{p} 42$. Brees also needed to make as much money from the images as possible since Wakefield was unable to pay him for part of his three year contract, and in lieu of payment signed the rights to the images over to Brees.

${ }^{37}$ Minson "Promotional Shots" p 162. Minson notes that the books all had clear promotional purposes - such as An Account of the Settlements of the New Zealand Company (1841), The New Zealand Portfolio (1843), New Zealand, South Australia and New South Wales (1841). the Tory in 1839. He was a last minute addition, but had a few months on the journey to figure out what was expected of him. Iain Sharp posits that Heaphy knew he was to produce "pleasing pictures for advertising purposes," but just what he would be picturing would have been unknown until he landed in New Zealand. ${ }^{38}$ While this is probably true in terms of the actual sites he was to capture on paper, Edward Gibbon Wakefield's theory of systematic colonisation was so well structured and known in Britain that it provided a detailed framework for the elements required in the Company's advertising.

You can hear the sniggers from authors as they point out a lithograph here or woodcut there was altered to further the purposes of the New Zealand Company. A hill may be lowered, plains widened, people added or ships stacked up in harbour - not what was "real." But the likes of Heaphy and Brees knew exactly what they were part of and what they were in place to do. It is not as though they were fine artists selling themselves off to the highest bidder - Sharpe perhaps describes it best when he notes that from the Company's

${ }^{38}$ Sharp Heaphy p 30. "point of view, after all, [Heaphy] was not a revered early New Zealand painter, just a dispensable junior employee."39 That a lithographer such as Thomas Allom - already an established artist and architect himself by the time he starting receiving Heaphy's paintings and sketches - did not alter the images more is testament to how aligned Heaphy was to the Company's vision (and potentially also their aesthetic merits). Murray-Oliver notes that Allom "was much more faithful to the original [Heaphy paintings] than many engravers were" 40 and Gil Docking notes that Melville's engravings for Brees' Pictorial Illustrations of New Zealand were "visually an improvement on the original paintings." 41

Their alignment with the Company's - and more precisely, with Wakefield's - way of thinking goes deeper than the fact surveying, exploring and land administration were natural fits with the colonial enterprise. It is fair to say that they were converts to the Company club, well versed in the language of systematic colonisation. Heaphy stated in his Narrative of a Residence in 1842 that he was not

${ }^{39}$ Sharp Heaphy p 65.

${ }^{40}$ Murray-Oliver "The Heaphy Lithographs" p 86.

${ }^{41}$ Docking Two Hundred Years p 31. 
simply writing what the Company told him, but "from having witnessed the successful working of the Company's plans, I am inclined to think that its system of colonization is the best."42 Deep in his text we can find clear statements of his conversion "no part of the world can now remain waste for any length of time, whilst the overburdening population of Europe requires an outlet."43 Brees spoke of "the redemption and occupation of wasteland"44 in Pictorial Illustrations of New Zealand, which was produced well after he left the employment of the Company in 1845. The Right Honourable Sir William Fox (KCMG) must be convert supreme - starting as agent for the Company in the mid-1840s, succeeding Edward Gibbon Wakefield as Company principal in 1848, later leading the Wakefieldian wastelands charge in New Zealand's first parliaments, becoming Commissioner of Crown Lands, and eventually Premier of New Zealand (a post he held four times). Fox's paintings openly expressed his concern with potential productivity, with Cheryl Sotheran noting it was "evident that he was more moved by the agricultural possibilities of the New Zealand

${ }^{42}$ Heaphy Narrative of a Residence pp vii-viii.

${ }^{43}$ Heaphy Narrative of a Residence pp 111.

${ }^{44}$ Brees Pictorial Illustrations pp 3-4. landscape than he was by its daunting emptiness." 45

\section{the improvement of labour}

Edward Gibbon Wakefield's theory of systematic colonisation was conceived at a time when many in Britain's leading circles were uncertain whether the benefits of colonies outweighed their costs. His theory released the financial burden of colonial ventures from the home country, funding emigration from land sales rather than taxes or other government funding. This solution was praised by economists of the time such as Jeremy Bentham and John Stuart Mill who saw it as helping to alleviate Britain's economic ills of the early nineteenth century. ${ }^{46}$ Wakefield required two central elements to be in place for his theory of systematic colonisation to work - first, the setting of a "sufficient price" for land, and second, the distribution of the waste lands needed to be done in a controlled manner (not a frontier free-for-all).

If land was too cheap there would be little incentive to work the land as productively as

45 Sotheran "Later Paintings" p 47.

${ }^{46}$ Kittrell "Wakefield's Scheme" p 101. possible, making it easier for settlers to simply gather more unproductive land as a way to increase wealth. Wakefield saw this as one of the issues of America and Australia, resulting in largely unplanned settlement that levelled society down "to the lowest common denominator and which lacked civilisation and culture." 47 Avoiding this required a balancing of capital and labour - land had to be priced so that the incentive was on the owner to pay fair wages for labour that would improve the land and generate greater economic benefit. This also led to a mobile society, where labourers would receive high wages and eventually purchase their own land, repeating the cycle with new emigrant labourers. If land was too expensive, then this mobility would be stymied. The sufficient price was somewhere in between and was vital to unlocking not only the economic benefits but also the vision of a new world society that Wakefield held.

Productive land was good land in Wakefield's model. His thinking was underpinned by Enlightenment philosopher John Locke's labour theory of property, which posited that a right to property only arose when an

${ }^{47}$ Martin "A "Small Nation on the Move"' p 110. 
individual worked the land, their labour entered into it and thereby made it their property. It was through labour that land gained value - planting it or grazing it generated far more value than leaving it "lying in common." Land lying in common never had its abilities fully realised since noone was incentivised to make it as productive as possible, and therefore individualisation of property right was needed to ensure land would be cultivated to its full capacity. Ten acres of cultivated land, Locke describes in his Second Treatise, would yield as much as one hundred acres of wild land held in common and even this was a conservative estimate. 48

The full benefits of Locke's labour theory of property only occurred when the land was cultivated and enclosed - as had occurred in the British agrarian revolution. ${ }^{49}$ The original meaning of the term enclosure focused on the formal and informal methods of removing communal rights and ownership over land and replacing this with a system of individual ownership and access. ${ }^{50}$ Physical separation of the land with fences or hedges often

\footnotetext{
${ }^{48}$ Locke Second Treatise chapt 5, section 41.

${ }^{49}$ Arneil John Locke and America p 140.

${ }^{50}$ Kain et al The Enclosure Maps of England and Wales
} 1595-1918 p 1. accompanied the act of enclosure, and eventually became synonymous with the original meaning, but was not necessary for enclosure to take place. Surveying was the important tool for enclosure, providing a conceptual delineation that set the foundations for individual claims to identifiable sections and subdivisions, regardless of whether physical separation existed.

Locke also set up a framework to distinguish between vacant, waste, and valuable land. Vacant land is untouched by human hands seemingly never cultivated in a low-intensity manner nor used for regular foraging or wild harvesting. Waste land is used to refer to "soil that has not been properly tended." 51 Locke also uses the term "neglected" to refer to waste land, implying that people who had cultivated land but allowed it to revert had "neglected" it and thereby released their rights (or at least given opportunity to others to apply their labour to it). The strongest distinction is that between waste land and productive, valueladen land, setting up "a foundational binary" 52 that reflected broader oppositions in

\footnotetext{
${ }^{51}$ Arneil John Locke and America p 142
}

${ }^{52}$ Whitehead "John Locke" p 85.
Locke's thinking such as savagery versus civilisation and nature versus culture.

\section{Where are all the people, Mum? ${ }^{53}$}

Emptiness has always had a strong presence in the New Zealand landscape tradition. In the nineteenth century, Hamish Keith points out that "the people were certainly there, but their presence was an inconvenient reality for land-hungry settlers"54 and that "there is nothing like the sight of an empty landscape to stimulate avarice for land in the heart of a potential settler who has none." ${ }^{55}$ Priscilla Pitts sees it similarly, noting how it was expedient for early nineteenth century artists "to expunge any signs of prior occupation from representations of the "new found land"."56 The idea of an empty land fits best with the concept of terra nullius ${ }^{57}$ in the context of colonisation. Terra nullius

${ }^{53}$ Hamish Keith demonstrates the persistence of the empty landscape in New Zealand art by referencing Pat Hanly's 1962 painting of Mount Eden which asks "Where are all the people, Mum?" Keith The Big Picture p 52.

${ }^{54}$ Keith The Big Picture p 52.

${ }^{55}$ Keith The Big Picture p 70.

${ }^{56}$ Pitts "The Unquiet Earth" p 88.

57 "Nobody's land," "empty land," "land belonging to noone," or "land owned by no-one" - to give you a flavour of the disputed nature of the concept. 
provided a justification for colonial powers to take control of "empty" land that had yet to be claimed by other European powers. It enabled acquisition through occupation, the extension of sovereignty over land without the need for treaty, annexation or invasion. As Anna Johnston and Alan Lawson put it "[e]mpty land can be settled, but occupied land can only be invaded." 58

The empty land thesis is compelling, but does not fit with the reality of Wakefieldian visions and the wastelands concept. Many of the images completed by Heaphy, Brees, Mein Smith and Fox feature inhabitants, and at times also their inhabitations. Lithographers such as Allom and Melville added more inhabitants into the scenes where they felt - or by suggestion of Company directors - more were needed. The wastelands concept accepts that people are here, and the New Zealand Company wanted potential emigrants to view Māori as refined, approachable, civilised: a potential source of skilled labour and certainly not a threat. ${ }^{59}$ But in no way will it be shown

${ }^{58}$ Johnston \& Lawson "Settler Colonies" p 362.

${ }^{59}$ Sharp Heaphy p 44. When Adventure in New Zealand was published in 1845 it excluded Heaphy's portraits of Te Rauparaha and Te Rangihaeta due to their involvement in the Wairau massacre. Te Puni and Te that Māori are using all their land to its fullest potential. Small tracts may depict cultivation or husbandry (showing civilisation through cropping and peacefulness through effort going into agriculture rather than war) ${ }^{60}$ but there is no suggestion that all land was under enclosure (i.e. intensively cultivated). If too much was being productively used by Māori, the price of land would be too high and the method of systematic colonisation would break down.

\section{not the work of a mere artist, but of a} surveyor ${ }^{61}$

The images used by the New Zealand Company were a vehicle for the model of systematic colonisation and its embedded wastelands concept. The fact that the New Zealand Company was so organised in its media and marketing approach shows that it cared deeply about what its images were depicting and the messages being communicated. Mitchell's claim that power is

Wharepōuri were considered to match the Company's brand and their portraits were included. See also

Murray-Oliver "The Heaphy Lithographs" p 86 and Minson "Promotional Shots" pp 160-161.

${ }^{60}$ Minson "Promotional Shots" p 161.

${ }^{61}$ From a review of Brees' panorama in Leicester Square by The Times, quoted in Bagnall et al "S.C.Brees" p 42. the best mode of analysis for landscape (which he eases back slightly from in later editions of his book Landscape and Power) are perhaps strongest in these images, enhanced by their use for commercial purposes. These were not hung in an aristocrat's drawing room only to gain wider audience upon posthumous exhibition - these were tools for convincing the masses of the virtues of following the Company's way.

In analysing images of New Zealand's colonisation based on the concept of the waste lands, we are looking for three key elements (from Locke through to Wakefield):

A. Enclosure and the individualisation of property rights.

B. Productivity, either latent or demonstrated. This may or may not be accompanied by depictions of waste or vacant land.

C. Colonisation being carried out in an ordered, controlled manner.

Below I consider two sets of images to demonstrate how these elements were prominent in the Company's work. The first are by Charles Heaphy, depicting Wellington in the early 1840s and the accompanying lithographs completed by Thomas Allom. The second are the images Edward 
Jerningham Wakefield's Illustrations to Adventure in New Zealand published in 1845.

\section{" $x$ " marks the spot}

In September 1841 the New Zealand Journal published a half-page woodcut titled "Thorndon Flat, and Part of the City of Wellington, the First New Zealand Settlement."62 It was accompanied by a similarly sized image titled "Key to the View of the City of Wellington," the two images together occupying a full page. Charles Heaphy - at that time nearly two years into his employment with the New Zealand Company but still only 21 years old - is not mentioned in the title or body text as being the creator of the original image. The woodcut was taken from Heaphy's watercolour of the same name, completed in April 1841. Thomas Allom completed a lithograph of the original watercolour - along with a version of the key - with both available for sale in October the same year. A one paragraph comment on the image finally appeared in the 2 October 1841 edition of the New Zealand Journal, noting the fine execution by Heaphy.

Enclosure and individualisation of property

62 "Thorndon Flat" p 232.

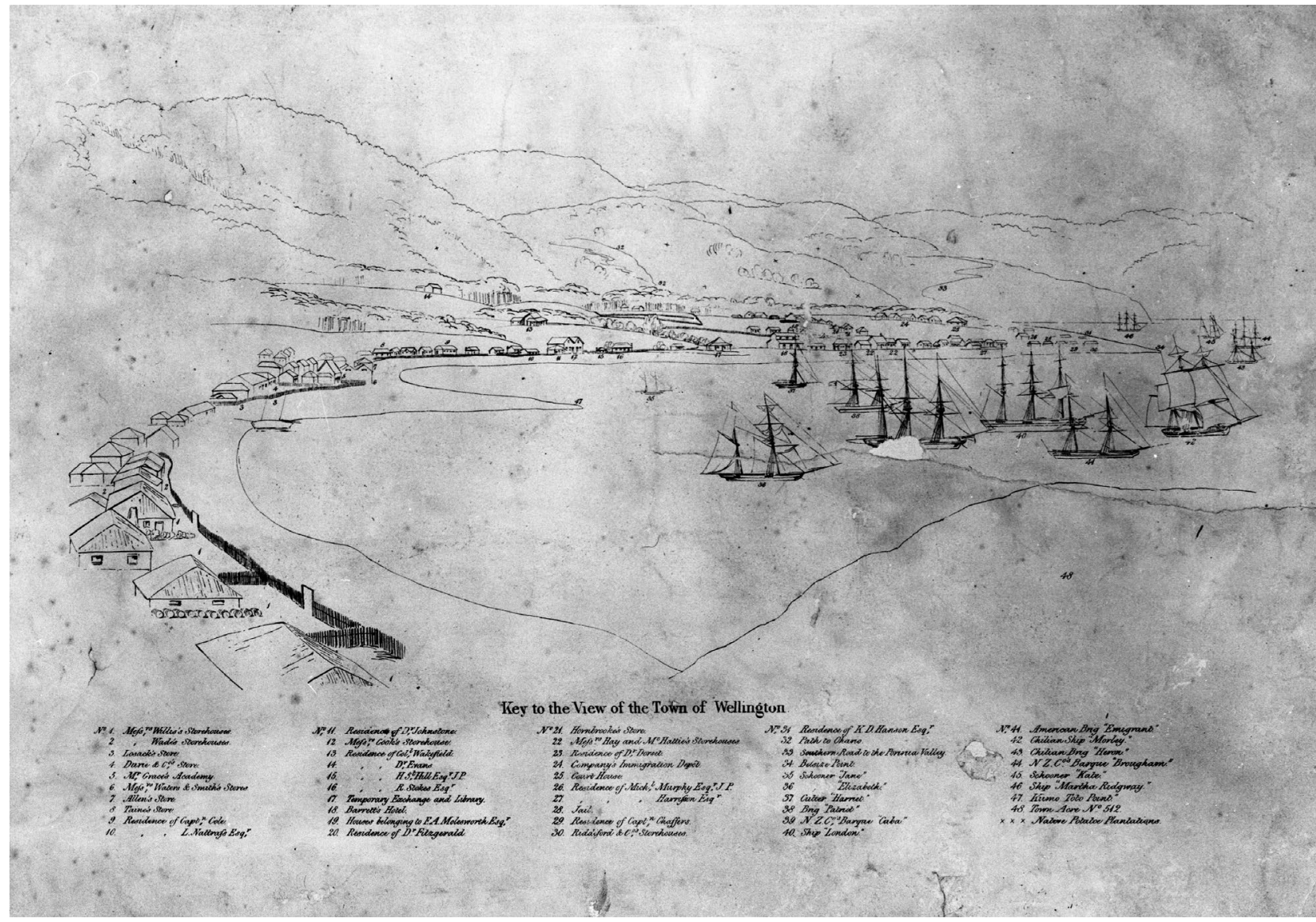

Figure 1: Heaphy, Charles 1820-81: Part of Lambton Harbour, in Port Nicholson, New Zealand; comprehending about one third of the water frontage of the town of Wellington, April, 1841. Drawn by Charles Heaphy, Thomas Allom lithographer. London, Published for the New Zealand Company by Smith Elder \& Co. printed by C. Hullmandel [1842]. Ref: C-026-001-g. Alexander Turnbull Library, Wellington, New Zealand. http://natlib.govt.nz/records/22516333

rights are shown by two main devices in these images. The viewer's eye is drawn from the bottom left corner of the image along the numerous houses spaced closely together, over to Thorndon Flat where the scene opens out more. The buildings in the foreground 
each have a fenced section to demonstrate that these are individual dwellings and that they are set out in an orderly manner (the work of a surveyor no doubt). A strong sense of order is reinforced by the sweep of dwellings, curving around the harbour with almost all facing toward the sea.

It is the key that speaks strongest to enclosure and individualisation. Each numbered dwelling is attributable to a single identifiable owner - "7. Allen's store," "No.21 Hornbrooke's store," "No.11 Residence of Dr Johnstone," "19. Houses belonging to F.A. Molesworth Esq" etc. This is a map to those who have successfully staked their claim and built their home and business in the new land. As a group these individuals contain all the elements of a successful settlement - doctors, teachers, law keepers, and also a tavern. But the whole is only successful due to being a collection of individuals.

The only reference to a Māori presence is the final mention in the list - "x x x Native Potatoe Plantations." This contrasts starkly with the list of individually named owners; the plantations are land owned in common. The six marked plantations, while worthy of being mentioned, are not given an individual number like the dwellings and ships. There is no enclosure or individualisation - the " $x$ " marking the spot is a general indication that leaves us none the wiser as to the size, yield or state of the plantations. Even the newly formed settlement has fences enclosing the small lots in the midground of the image, each with their attendant dwelling (including Colonel Wakefield's at No.13).

There is no immediately obvious sign of these plantations in Heaphy's original watercolour, and it is only in the key (both Allom's lithograph and the New Zealand Journal woodcut version) that the locations are revealed. They are pretty much just clearings in the lightly clad bush, or open sites on a gently sloping hill. We are also unable to see any obvious sign of intensive cultivation of the potato plantations. Marking these spots also works to release the surrounding land from any usage - perhaps vacant land, at least wasteland - available and suitable for agricultural use by settlers when released in an orderly manner.

\section{a very fair representation of the wretched dwelling places}

Edward Jerningham Wakefield had colonialism in his blood. He travelled to New
Zealand in 1839 with the likes of Charles Heaphy aboard the Tory, aged 19. Four years later he returned to London and was encouraged by his father - Edward Gibbon Wakefield - to collate his journal notes and publish them as a book which made the case for the theory of systematic colonisation. ${ }^{63}$ Adventure in New Zealand 1839-1844: with Some Account of the Beginnings of the British Colonization of the Islands was published in 1845 and was a raging success. ${ }^{64}$

Adventure in New Zealand was accompanied by a folio of illustrations: 16 pages of lithographs completed by Thomas Allom, taken from original works by Heaphy, Brees, Mein Smith, Emma Wicksteed, John Saxton, and Martha King. It has largely been overlooked as a collection, with its individual images receiving the attention. Leonard Bell calls it a "celebration of the progress of the New Zealand Company settlements, plus a sprinkling of beneficent Maoriana" before going on to discuss at length publications by Angas and Brees. ${ }^{65}$ Gordon Brown and Hamish Keith give the collection more of a serve, noting that it "is a good example of the

${ }^{63}$ Steer "Forms of Settlement" p 67.

${ }^{64}$ Cooper "Wakefield" n.p.

${ }^{65}$ Bell Colonial Constructs p 19 
levelling process of commercial lithography" with none of the images bearing "any relationship to the characteristic qualities of the New Zealand landscape."66

Five of the images in Illustrations to Adventure in New Zealand were botanical studies by Martha King. Three were portraits of local Māori, and three of Māori habitations and dwellings. The remainder were landscapes of Company settlements (existing and prospective), including five multi-page fold out panoramas. The landscapes all contain the three wastelands elements: enclosure, productivity, and orderly settlement. Wicksteed's panorama of New Plymouth shows the inhabitants working industriously on their lots, fences defining them from their neighbours, and the names along the bottom of the image telling us which individual owned what. Saxton's sweep across Nelson is led by a surveyor in the middle foreground, gazing upon the well-laid out roads and dwellings that occupy the image from one side to the other. Productive farms are fenced and planted, markets and a brick kiln are in place. It is only Brees' two-page panorama of the Plain of the Ruamahunga that offers little

${ }^{66}$ Brown and Keith New Zealand Painting p 15.

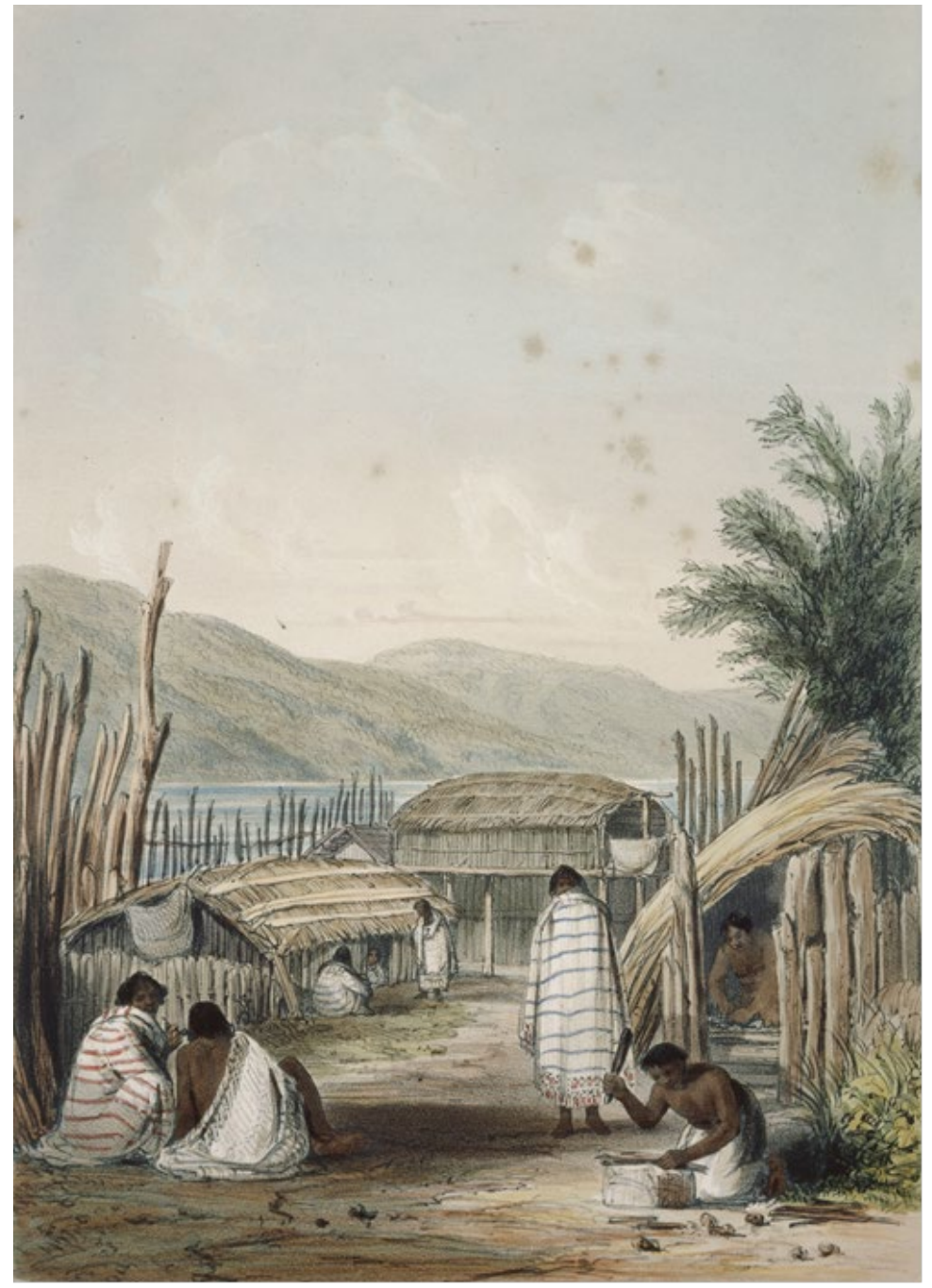

Figure 2: Smith, William Mein 1799-1869: Courtyard in Pipitea Pā at Wellington. Drawn in 1842 by Captain William Mein Smith, R. A. Day \& Haghe. London, Smith, Elder [1845]. Wakefield, Edward Jerningham 1820-1879: Illustrations to "Adventure in New Zealand" Lithographed from original drawings taken on the spot by Mrs Wicksteed, Miss King, Mrs Fox, Mr John Saxton, Mr Charles Heaphy, Mr S. C. Brees and Captain W. Mein Smith. London, Smith Elder \& Co, 1845. Ref: PUBL-0011-04-1. Alexander Turnbull Library, Wellington. http://natlib.govt.nz/records/23151660 
for a wastelands analysis, instead showing a vast sweep of largely empty land (vacant to learn from Locke) and relying on comments about roads and distant settlements to communicate an intended ordered approach to settlement.

Māori are missing from most of the landscapes, and even when they do appear they are largely incidental. Three Māori figures helpfully accompany the explorers in Brees' "Plain of the Ruamahunga," but there is no sign that they occupied or worked any of the land shown. Wicksteed's panorama of New Plymouth notes "native PA, now Removed," reflecting comments in Adventure in New Zealand that local Māori had abandoned their pā and cultivations in the area (wasteland due to being neglected). ${ }^{67} \mathrm{No}$ sign nor mention of Māori is made in Saxton's view of Nelson or in Mein Smith's view of Petre (Whanganui). ${ }^{68}$ Te Rauparaha camps at a safe distance in Brees' view of Porirua

${ }^{67}$ Wakefield Adventure in New Zealand pp 350-355. This refers to Puke Ariki pā.

${ }^{68}$ Mein Smith's view of Petre does note that Edward Jerningham Wakefield's house is called "Ware

Wikitoria." More interesting is that Mein Smith chose this view looking up river rather than across. Brees'

1844 image of the town turns to look south across the city and over the river, thereby including Pūtiki marae. harbour, with no sign of permanent settlement or cultivation. The portraits of Epuni and Wharepouri are effectively interiors, the landscape behind them tightly constrained compared to the sweeping vistas of the panoramas in the following pages.

Of most interest for this paper are the images of Pipitea pā by Mein Smith and Otumatua pā by Heaphy. These are also interior images, and with the portraits they provide a contrast to the landscapes in the rest of the folio. Several dwellings are shown, but none are identified as belonging to any individual - the text accompanying Heaphy's Otumatua pā simply states that in the "background is a ware puni or sleeping-house." This is in direct opposition to the other landscapes with their annotations on which individual owned which building. The message is that while the pā may be fenced, that does not mean they are enclosed, and that this is land owned in common. Order does not exist either, with no clearly defined paths, and our view of Pipitea pā affords us no comfort that the dwellings are arranged in a structured or planned manner.

Some strong messages are also sent about productivity in these two images. The Māori shown in both are either at leisure or occupying themselves with subsistence activities. None are engaged in highproductivity work like that often shown in the other landscape images - for example the surveyor in Saxton's view of Nelson or unloading wood from a ship as in Mein Smith's view of Petre. It especially contrasts with the sawmilling gang shown in Heaphy's A Sawyer's Clearing in a Forest of Kauri that was also published in Illustrations. The only industrious Māori figure is beating harakeke or similar - repeated in each image, this depiction tells us that no matter where in the country Māori are they are engaged in low productivity endeavours. Heaphy's image of Otumatua pā does display an abundance of potato or kūmara, stacked in bags at the foot of the pātaka. When read in conjunction with the lack of any cultivation in the other landscapes, the message is that Māori have ample land elsewhere to provide for themselves. The land in the panoramic views of Nelson, New Plymouth, Wellington and the Wairarapa must therefore be wasteland.

The text accompanying Mein Smith's image of Pipitea pā tells us that it "affords a very fair representation of the wretched dwelling places from which the natives are 
recommended by their Official Protectors never to remove." At first glance this is a typical comment aligned with the foundational binaries in John Locke's thinking (savage versus civilisation), but instead it is highlighting the need for ordered and structured settlement. Fundamental to systematic colonisation is the avoidance of the "evils of frontier societies."69 Isolated pockets of Māori were to be avoided, and the tenths approach to native reserves was intended to distribute Māori around the settlement. The land set aside for Māori would increase in value allowing them to "preserve their chiefs in circumstances equal to those of the higher order of settlers in future times."70 The expectation in the Wakefield model - and point of contention with the Crown - was that existing isolated, concentrated and poorly worked pā needed to be freed up. The fear was that Māori would have no incentive to intensify efforts at their existing pā, dragging the whole settlement down due to the concentration of their numbers. Distribution around native reserves would dissipate this risk, ensuring no pockets of wasteland existed in the centre of settlements, and systematic

${ }^{69}$ Olssen "Mr. Wakefield and New Zealand as an Experiment" p 205.

${ }^{70}$ Wakefield Adventure in New Zealand p 39. colonisation would stay on track.

a natural law almost as certain as gravitation The waste lands concept is important for understanding the complex interactions between the land, Māori, Crown and settlers in New Zealand in the mid nineteenth century. This importance is shown by its infusion through Edward Gibbon Wakefield's thoughts and actions on "systematic colonisation" and the accompanying wastelands concept, helping us understand how land (and space) as it related to Māori at the time was viewed by European emigrants.

Analyses of landscapes from the 1840s have generally been approached from a fine arts lens. This has evolved from a search for the "true" New Zealand in art (which baulked at anything less than fine art), through a more encompassing phase that sought recognition of a number of artistic approaches to landscape, and eventually to the territory of landscape as a colonial tool - though still with a fine arts focus. Recent research by the likes of Simon Dench and Felicity Barnes break the bonds of fine art history by examining photographic evidence.

Images used by the New Zealand Company fall into a similar category. The creators of the original images were Company converts (not just employees), and the commercial use of the images meant they achieved a very wide audience. Given the effectiveness of the Company's marketing machine, these images were strong vehicles for the philosophies that underpinned the Wakefield theory of systematic colonisation, and in particular the wastelands concept. Understanding the links between these intentions (as Mitchell and Dench call them) and the images gives us a stronger understanding of how New Zealand space was being constructed in the mid nineteenth century. It also gives us a view into relationships between Māori and European settlers, since these images also show this was contested space.

Even today you can hear echoes of New Zealand's spatial establishment. As a nation that still earns a large part of its living from the land we are often consumed by gaining more productivity from it. We are also a nation obsessed with investing and profiting from land, a habit that reaches back to the first settlers. Belich notes that the New Zealand Company also sold the image of an investors' paradise. Ultimately part of its downfall, the original Company plan relied on a small 
number of section purchasers being absentees, investing their spare cash rather than making the trip out themselves - "[t]hat land values would double every three years was "a
natural law
almost
as
certain

gravitation"."71

${ }^{71}$ Belich Making Peoples p 307. 


\section{REFERENCES}

Arneil, Barbara John Locke and America: the Defence of English Colonialism Oxford: Oxford University Press, 1996.

Bagnall, AG "S.C. Brees, Artist and Surveyor" The Turnbull Library Record (1968) 1(4):36-53.

Belich, James Making Peoples: a history of the New Zealanders, from Polynesian Settlement to the End of the Nineteenth Century Auckland: Allen Lane; Penguin, 1996.

Bell, Leonard Colonial Constructs. European Images of Māori 1840-1914 Auckland: Auckland University Press, 1992.

Brees, S. C. Pictorial Illustrations of New Zealand London, 1849.

Brown, Gordon H Visions of New Zealand. Artists in a New Land Auckland: David Bateman, 1988.

Brown, Gordon H. \& Hamish Keith Introduction to New Zealand Painting 1839-1967 Auckland: Collins, 1975.

Byrnes, Giselle Boundary Markers: Land Surveying and the Colonisation of New Zealand Wellington: Bridget Williams Books, 2001.

Carter, Paul The Road to Botany Bay. An Exploration of Landscape and History Minneapolis: University of Minnesota Press, 1987.

Colligan, Mimi Canvas Documentaries: Panoramic Entertainments in Nineteenth-century Australia and New Zealand Melbourne: Melbourne University Press, 2002.

Cooper, Ronda "Wakefield, Edward Jerningham" Dictionary of New Zealand Biography. Te Ara - the Encyclopedia of New Zealand http://www.TeAra.govt.nz/en/biographies/1w5/wakefield-edwardjerningham.

Day, Patrick Making of the New Zealand Press: a study of the organizational and political concerns of New Zealand newspaper controllers, 1840-1880 [Wellington]: Victoria University Press, 1990.

Dench, Simon "Invading the Waikato: A Postcolonial Review" New
Zealand Journal of History (2011) 45(1):33-49.

Docking, Gil Two Hundred Years of New Zealand Painting Auckland: A.H. \& A.W. Reed, 1971.

Heale, Theophilus New Zealand and the New Zealand Company, Being a Consideration of How Far Their Interests Are Similar London: Sherwood, Gilbert, and Piper, 1842.

Heaphy, Charles Narrative of a Residence in Various Parts of New Zealand. Together with a Description of the Present State of the Company's Settlements London: Smith, Elder and Co, 1842.

Johnston, Judith "Information and Emigration: The Image Making Process" New Zealand Geographer (October 1977) 33(2):60-67.

Johnston, Anna \& Alan Lawson "Settler Colonies" A Companion to Postcolonial Studies: a historical introduction ed Sangeeta Ray \& Henry Schwarz, Malden, MA: Blackwell Publishers, 2005: 360-376.

Kain, Roger, John Chapman and Richard R. Oliver The Enclosure Maps of England and Wales 1595-1918 Cambridge: Cambridge University Press, 2004.

Keith, Hamish The Big Picture. A History of New Zealand Art from 1642 Auckland: Random House, 2007.

Kittrell, Edward R. "Wakefield's Scheme of Systematic Colonization" The American Journal of Economics and Sociology (January 1973) 32(1):87-112. Landscape and Power ed. W.J.T. Mitchell, Chicago: University of Chicago Press, 1994.

Locke, John Second Treatise of government London: 1764.

Martin, John E "A "Small Nation on the Move": Wakefield's Theory of Colonisation and the Relationship Between State and Labour in the Mid-Nineteenth Century" Edward Gibbon Wakefield and the Colonial Dream Wellington: Friends of the Turnbull Library, 1997: 106-122. Minson, Marian "Promotional Shots: the New Zealand Company's 
Paintings, Drawings and Prints of Wellington in the 1840s and Their Use in Selling a Colony" Edward Gibbon Wakefield and the Colonial

Dream: A Reconsideration Wellington: GP Publications, 1997: 159-166.

Murray-Oliver, Anthony "An Enquiry into Certain Nineteenth Century Prints. The Heaphy Lithographs" The Turnbull Library Record (1971) 4(2):74-94.

Olssen, Erik "Mr. Wakefield and New Zealand as an Experiment in PostEnlightenment Practice" New Zealand Journal of History 1997 31(2):19721

Park, Geoff "Edward Gibbon Wakefield's Dream, Thomas Shepherd's Eye and New Zealand's Spatial Constitution" Geoff Park Theatre Country. Essays on Landscape and Whenua Wellington: Victoria University Press, 2006: 34-42.

Pitts, Priscilla "The Unquiet Earth. Reading Landscape and the Land in New Zealand Art" ed Barr, Mary Headlands: Thinking Through New Zealand Art Sydney: Museum of Contemporary Art, 1992: 87-98.

Pool, Ian "Population change" Dictionary of New Zealand Biography. Te Ara - the Encyclopedia of New Zealand http://www.TeAra.govt.nz/en/graph/28720/new-zealand-populationby-ethnicity-1840-2006.

Pound, Francis Frames on the Land. Early Landscape Painting in New Zealand Auckland: Collins, 1983.

Sharp, Iain Heaphy Auckland: Auckland University Press, 2008.

Skinner, Robin "Representations of architecture and New Zealand in London, 1841-1860" Auckland: University of Auckland PhD thesis, 2007.

Somerset, Guy "Selling the Dream: The Art of Early New Zealand Tourism - review" Listener (6 October 2012) 3778: 45.

Sotheran, Cheryll "The Later Paintings of William Fox" Art New Zealand (Spring 1978) 11:42-49.
Steer, Phillip "Forms of Settlement: Colonial Space, Time and Genre from Adventure in New Zealand to The Fossil Pits" New Zealand Journal of Literature (2010) 28(2):58-81.

Temple, Philip A Sort of Conscience: the Wakefields Auckland: Auckland University Press, 2002.

"Thorndon Flat, and Part of the City of Wellington, the First New Zealand Settlement" New Zealand Journal (18 September 1841) 44:232.

Wakefield, E.J Adventure in New Zealand London: Smith, Elder \& Co, 1845.

Wakefield, E.J Illustrations to "Adventure in New Zealand" London: Smith, Elder \& Co, 1845

Whitehead, Judy "John Locke and the Governance of India's Landscape: The Category of Wasteland in Colonial Revenue and Forest Legislation" Economic and Political Weekly (December 11, 2010) 45(50):83-93. 